medRxiv preprint doi: https://doi.org/10.1101/2021.03.29.21254565; this version posted March 31, 2021. The copyright holder for this preprint (which was not certified by peer review) is the author/funder, who has granted medRxiv a license to display the preprint in perpetuity.

It is made available under a CC-BY-NC-ND 4.0 International license .

\title{
Title: Pediatric household transmission of SARS-CoV-2 infection
}

Authors:

Lauren A. Paul, MSc ${ }^{\mathrm{a}}$

Nick Daneman, $\mathrm{MD}^{\mathrm{a}-\mathrm{e}}$

Kevin L. Schwartz, MD ${ }^{\text {a,f,g }}$

Michelle Science, MD $^{\mathrm{a}, \mathrm{h}, \mathrm{i}}$

Kevin A. Brown, $\mathrm{PhD}^{\mathrm{a}, \mathrm{f}}$

Michael Whelan, $\mathrm{MSc}^{\mathrm{a}}$

Ellen Chan, $\mathrm{MSc}^{\mathrm{a}}$

Sarah A. Buchan, PhD ${ }^{\text {a,f }}$ lauren.paul@oahpp.ca

nick.daneman@sunnybrook.ca

kevin.schwartz@oahpp.ca

michelle.science@oahpp.ca

kevin.brown@oahpp.ca

michael.whelan@oahpp.ca

ellen.chan@oahpp.ca

sarah.buchan@oahpp.ca

Affiliations:

${ }^{a}$ Health Protection, Public Health Ontario, 661 University Ave., Floor 17, Toronto, ON, M5G 1M1, Canada

${ }^{\mathrm{b}}$ Sunnybrook Research Institute, Sunnybrook Health Sciences Centre, 2075 Bayview Ave., Toronto, ON, M4N 3M5, Canada

${ }^{c}$ Division of Infectious Diseases, Sunnybrook Health Sciences Centre, 2075 Bayview Ave., Room B1 03, Toronto, ON, M4N 3M5, Canada

dDepartment of Medicine, University of Toronto, 6 Queen's Park Cres. W, Floor 3, Toronto, ON, M5S 3H2, Canada e Institute of Health Policy, Management and Evaluation, University of Toronto, 155 College St., Suite 425, Toronto, ON, M5T 3M6, Canada

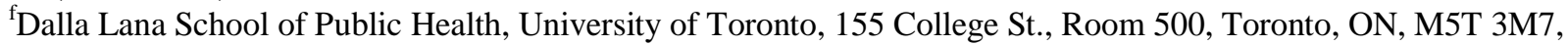
Canada

${ }^{\mathrm{g}}$ Unity Health Toronto - St. Joseph's Health Centre, 30 The Queensway, Toronto, ON, M6R 1B5, Canada

${ }^{\mathrm{h}}$ Division of Infectious Diseases, The Hospital for Sick Children, 555 University Ave., Clinic 7, Toronto, ON, M5G

1X8, Canada

${ }^{\mathrm{i} D e p a r t m e n t}$ of Paediatrics, University of Toronto, 555 University Ave., Black Wing Room 1436, Toronto, ON, M5G 1X8, Canada

Corresponding Author:

Sarah Buchan, PhD

Public Health Ontario

661 University Avenue, Floor 17

Toronto, Ontario, M5G 1M1

Tel: 647-260-7274

Email: sarah.buchan@oahpp.ca 
medRxiv preprint doi: https://doi.org/10.1101/2021.03.29.21254565; this version posted March 31, 2021. The copyright holder for this preprint (which was not certified by peer review) is the author/funder, who has granted medRxiv a license to display the preprint in perpetuity.

It is made available under a CC-BY-NC-ND 4.0 International license .

\begin{abstract}
BACKGROUND: As a result of low numbers of pediatric cases early in the COVID-19 pandemic, pediatric household transmission of SARS-CoV-2 remains an understudied topic. This study sought to determine whether there are differences in the odds of household transmission for younger children compared to older children.

METHODS: We assembled a cohort of all individuals in Ontario, Canada with laboratory-confirmed SARS-CoV-2 infection between June 1 and December 31, 2020. The cohort was restricted to individuals residing in private households ( $\mathrm{N}=132,232$ cases in 89,191 households), identified through an address matching algorithm. Analysis focused on households in which the index case was aged $<18$ years. Logistic regression models were fit to estimate the association between age group of pediatric index cases (0-3, 4-8, 9-13, and 14-17 years) and odds of household transmission.
\end{abstract}

RESULTS: A total of 6,280 households had pediatric index cases, and 1,717 (27.3\%) experienced secondary transmission. Children aged 0-3 years had the highest odds of household transmission compared to children aged 1417 years (model adjusted for gender, month of disease onset, testing delay, and average family size: 1.43, 95\% CI: 1.17-1.75). This association was similarly observed in sensitivity analyses defining secondary cases as 2-14 days or 4-14 days after the index case, and stratified analyses by presence of symptoms, association with a school/childcare outbreak, or school/childcare reopening. Children aged 4-8 years and 9-13 years also had increased odds of transmission (4-8: 1.40, 95\% CI: 1.18-1.67; 9-13: 1.13, 95\% CI: 0.97-1.32).

CONCLUSIONS: This study suggests that younger children are more likely to transmit SARS-CoV-2 infection compared to older children, and the highest odds of transmission was observed for children aged 0-3 years. Differential infectivity of pediatric age groups has implications for infection prevention controls within households, as well as schools/childcare, to minimize risk of household secondary transmission.

KEYWORDS: COVID-19; SARS-CoV-2; household; transmission; children; pediatric; age; school-aged 
medRxiv preprint doi: https://doi.org/10.1101/2021.03.29.21254565; this version posted March 31, 2021. The copyright holder for this preprint (which was not certified by peer review) is the author/funder, who has granted medRxiv a license to display the preprint in perpetuity.

It is made available under a CC-BY-NC-ND 4.0 International license .

\section{Acknowledgements}

The authors thank James Johnson and Arezou Saedi for conducting the address-matching work, Trevor van Ingen for providing the neighbourhood-level data, and Semra Tibebu for cleaning the individual-level household size variable.

\section{Contributors}

LP performed the analysis and drafted the manuscript. SB, ND, KS, MS, and KB conceptualized the study. SB, ND, KB, KS, MS, MW, and LP developed the methodology. SB, KB, and LP verified the underlying data. SB, ND, KS, MS, KB, MW, and EC reviewed the manuscript.

\section{Declaration of interests}

The authors have no conflicts of interest to declare.

\section{Data sharing}

Data sharing requests should be directed to Public Health Ontario. 
medRxiv preprint doi: https://doi.org/10.1101/2021.03.29.21254565; this version posted March 31, 2021. The copyright holder for this preprint (which was not certified by peer review) is the author/funder, who has granted medRxiv a license to display the preprint in perpetuity. It is made available under a CC-BY-NC-ND 4.0 International license .

\section{Introduction}

The role of children in the transmission of severe acute respiratory syndrome coronavirus 2 (SARS-CoV-2) infection requires further study. Early in the pandemic, when countries implemented lockdown measures, close contact was mostly limited to households and testing strategies tended to prioritize healthcare workers and symptomatic individuals. ${ }^{1-4}$ As a result there were relatively few diagnosed pediatric cases of coronavirus disease 2019 (COVID$19)^{5}$ and it appeared that the proportion of children involved in the transmission of infection was small. ${ }^{2,6,7}$ Since many jurisdictions relaxed public health measures and re-opened educational facilities in the fall of 2020, the number of pediatric COVID-19 cases has grown, providing the opportunity to better characterize the infectivity of children.

Household studies to date have typically only compared infectivity between young and old individuals, often grouping children with young adults ${ }^{8-12}$ or dichotomizing age to older adults versus younger adults/children..$^{13,14}$ These studies have reported mixed results, with some finding that older age ( $\geq 20$ years) was associated with increased transmission ${ }^{6,8-10,15,16}$, one study finding younger age $(<20 \text { years })^{12}$, and others finding no age effect. ${ }^{11,13-}$ ${ }^{15,17-19}$ Conversely, few household studies have examined differences in transmission among children ${ }^{15,16,20-23}$, likely due to insufficient sample size., ${ }^{2,24}$ Two meta-analyses reported no significant differences between younger children and older children for household susceptibility to SARS-CoV-2 ${ }^{2,15}$, however it remains unclear if this holds true for infectivity. These findings warrant a closer look at household transmission of SARS-CoV-2 by children, and whether there are any differences in the likelihood of transmission for particular age groups.

We sought to conduct an age analysis of residents aged 0-17 years in Ontario, Canada that were the index case of SARS-CoV-2 infection in their household between June and December 2020. Pediatric index cases were divided into four age groups $(0-3,4-8,9-13$, and $14-17$ years) to provide a more granular picture of any age differences. We were also interested in comparing characteristics of index cases by age group, exploring the direction of transmission by age, and assessing whether factors such as symptoms, school/childcare reopening, or school/childcare outbreaks were associated with differences in the odds of transmission from children to their household members. 


\section{Methods}

\section{Study population}

We derived the study cohort from case data that was reported in provincial disease systems by health units across Ontario, Canada's most populous province. All individuals with laboratory-confirmed SARS-CoV-2 infection between June 1 and December 31, 2020 were included. We obtained ethics approval from Public Health Ontario's Research Ethics Board.

\section{Identification of private households}

Addresses of all cases were reviewed and classified as either private households, defined as individual houses or apartments/suites within multi-unit dwellings, or congregate settings (e.g., homeless shelters or long-term care homes). We excluded any individuals with missing or incomplete address information, individuals residing in congregate settings, and individuals identified as residing in multi-unit dwellings but missing suite information. Addresses were then matched between cases using a natural language processing algorithm from Python's "sklearn" library in order to identify multi-case households. Details of the address matching process have been described previously. $^{25}$

\section{Outcomes}

The outcome of interest was secondary household transmission of SARS-CoV-2 infection by a pediatric index case (aged 0-17 years). Index cases were defined as the earliest case of a household, and were identified by comparing symptom onset dates of all cases in the household. ${ }^{2}$ If symptom onset date was missing we used specimen collection date as a proxy; no cases were missing both dates. Secondary cases were defined as cases (adult or pediatric) that had disease onset 1-14 days after the index case, as per previous studies of household transmission., ${ }^{2,21,22,25} \mathrm{We}$ excluded households with index cases missing age $(\mathrm{N}=12)$, as well as households with multiple index cases (i.e., multiple cases occurring on the earliest case date of the household; $\mathrm{N}=4,335$ ), as they would present challenges for estimating associations between household transmission and characteristics of the index case.

\section{Individual-level and neighbourhood-level characteristics of index cases}

The main exposure of interest was age group of the index case: $0-3,4-8,9-13$, and 14-17 years. We also a priori selected a group of individual-level and neighborhood-level characteristics of the index case to adjust for in the models. At the individual-level, we included gender, month of disease onset, and testing delay between symptom 
medRxiv preprint doi: https://doi.org/10.1101/2021.03.29.21254565; this version posted March 31, 2021. The copyright holder for this preprint (which was not certified by peer review) is the author/funder, who has granted medRxiv a license to display the preprint in perpetuity.

It is made available under a CC-BY-NC-ND 4.0 International license .

onset and specimen collection. For the testing delay, we additionally categorized cases that were asymptomatic, identified as cases that were missing symptom onset date (thus specimen collection date was used) and were reported as asymptomatic in provincial reportable disease systems. As we only had individual-level household size information reported for $59.6 \%$ of index cases, we also included average family size for the neighbourhood of the index case. Average family size was available from 2016 Canadian census records for aggregate dissemination areas across Ontario, representing areas of approximately 5,000-15,000 persons.

For stratified and sensitivity analyses, we additionally included information on the presence of symptoms, whether the index case was linked to a school/childcare outbreak, and whether the index case's disease onset was before or after school/childcare reopening (depending on the age of the index case). In Ontario, schools reopened in midSeptember 2020 and childcare reopened mid-June 2020.

\section{Statistical analysis}

We carried out descriptive analyses to assess the characteristics of pediatric index cases across the four age groups, and included index cases aged $>17$ years for comparison. Direction of transmission from index case to secondary case by age was also examined. We then applied three logistic regression models to obtain odds ratios (OR) and 95\% confidence intervals (CI) for the associations between index case age group and odds of household transmission: (1) a crude, unadjusted model; (2) a model adjusted for gender and month of disease onset (adjusted model 1); and (3) a model adjusted for gender, month of disease onset, testing delay, and average family size (adjusted model 2).

For stratified analyses, these models were re-fit to subsets of the data broken down by three additional index case characteristics: (1) presence of symptoms; (2) association with a school/childcare outbreak; and (3) disease onset before school/childcare reopening.

For sensitivity analyses, we first updated the definition of secondary cases to increase certainty of the direction of transmission from the index case; we re-ran the analyses with secondary cases that developed symptoms 2-14 days after the index case and 4-14 days after the index case. Second, we adjusted for individual-level household size instead of neighbourhood-level average family size in the subset of index cases that had this information available. Third, we ran the analysis on a symptomatic cohort, restricting to index cases and secondary cases that had 
medRxiv preprint doi: https://doi.org/10.1101/2021.03.29.21254565; this version posted March 31, 2021. The copyright holder for this preprint (which was not certified by peer review) is the author/funder, who has granted medRxiv a license to display the preprint in perpetuity.

It is made available under a CC-BY-NC-ND 4.0 International license .

symptoms reported or a symptom onset date available. Last, we re-ran the symptomatic cohort analysis with the adjusted definitions for secondary cases (i.e., 2-14 days and 4-14 days).

\section{Results}

Between June and December 2020, a total of 6,280 private households had a pediatric index case (Figure 1). The mean age of pediatric index cases was 10.7 years and $45.6 \%$ were female. Of the 6,280 households, $1,717(27.3 \%)$ experienced secondary household transmission, leading to a median of 2 secondary cases (percentiles: $25^{\text {th }}=1$ case, $75^{\text {th }}=2$ cases, $90^{\text {th }}=3$ cases). Pediatric index cases most frequently transmitted infection to individuals aged 0-20 years or 30-50 years, with older children tending to transmit to older individuals in those age ranges (Figure 2).

The proportion of index cases in each age group increased with age, with $12 \%$ aged $0-3,20 \%$ aged $4-8,30 \%$ aged 9 13, and 38\% aged 14-17 (Table 1). Compared to index cases in the oldest age group, younger index cases had a higher proportion associated with a school/childcare outbreak and shorter testing delays. Index cases aged 4-8 years and 9-13 years had higher proportion with no symptoms reported compared to index cases 14-17 years or index cases 0-3 years. Across all age groups, more index cases had disease onset in the fall/winter (September-December) compared to the summer (June-August), which aligns with the trajectory of the second wave of the pandemic in Ontario.

\section{Associations with index case characteristics}

Compared to index cases aged 14-17 years, index cases aged 0-3 years had higher odds of household transmission in all three models (crude model OR=1.20,95\% CI: 1.01-1.44; adjusted model 1 OR=1.21, 95\% CI: 1.01-1.45; adjusted model 2 OR=1.43, 95\% CI: 1.17-1.75) (Table 2). There were no significant differences in the odds of transmission for the 4-8 and 9-13 year age groups, with the exception of adjusted model 2 for index cases aged 4-8 years $(1.40,95 \%$ CI: 1.18-1.67). Additionally, there were incremental odds of transmission with longer testing delays compared to a 0 -day delay (ORs: 1 -day delay=1.24, 2-day delay=1.59, 3-day delay=1.97, 4-day delay=2.38, $\geq 5$-day delay=2.98), as well as increased odds of transmission with larger average family size (1.63 per person increase, 95\% CI: 1.43-1.86). No significant differences were observed by gender or by month of disease onset.

In stratified analyses, we did not observe significant heterogeneity $(\mathrm{p}<0.05)$ in the odds of household transmission between index cases with versus without symptoms reported, index cases not associated versus associated with a 
medRxiv preprint doi: https://doi.org/10.1101/2021.03.29.21254565; this version posted March 31, 2021. The copyright holder for this preprint (which was not certified by peer review) is the author/funder, who has granted medRxiv a license to display the preprint in perpetuity.

It is made available under a CC-BY-NC-ND 4.0 International license .

school/childcare outbreak, or index cases with disease onset before versus after school/childcare reopening (Supplementary Tables 1 and 2).

Sensitivity analyses of the crude model and adjusted model 1 resulted in the same direction of association for the 0-3 year age group, but confidence intervals widened (Supplementary Table 3). In adjusted model 2, associations were largely unchanged with the 2-14 day definition, in the symptomatic case analysis, and when controlling for individual-level household size for the 0-3 year age group (adjusted model 2 OR=1.43, 95\% CI: 1.17-1.75; 2-14 day $\mathrm{OR}=1.37,95 \%$ CI 1.11-1.69; symptomatic OR=1.32, 95\% CI 1.06-1.64; household size OR=1.31, 95\% CI: $1.02-$ 1.67) and 4-8 year age group (adjusted model $2 \mathrm{OR}=1.40,95 \%$ CI: $1.18-1.67 ; 2-14$ day OR=1.33, 95\% CI 1.111.60; symptomatic OR=1.33, 95\% CI 1.10-1.61; household size OR=1.31, 95\% CI: 1.06-1.62). Associations for the 0-3 year and 4-8 year age groups were also similar to adjusted model 2 in the combined 2-14 day definition and symptomatic case analysis $(0-3$ year $\mathrm{OR}=1.25,95 \% \mathrm{CI} 1.00-1.57$; $4-8$ year $\mathrm{OR}=1.23,95 \% \mathrm{CI} 1.00-1.50)$, as well as for the $0-3$ year age group with the 4-14 day definition (1.35, 95\% CI 1.07-1.70) and after further restricting to symptomatic cases (1.26, 95\% CI 0.96-1.64).

\section{Discussion}

In this study of 6,280 pediatric index cases, we observed that children aged 0-3 years had greater odds of household transmission compared to children aged 14-17 years. This association was observed irrespective of factors such as presence of symptoms, school/childcare reopening, or association with a school/childcare outbreak. We also observed some evidence of greater odds of household transmission for children aged 4-8 years after controlling for testing delays and neighbourhood-level average family size (as well as individual-level household size). We identified clustering of ages in our age-to-age transmission plot, which likely reflects the age structure of households with younger pediatric cases living with, and transmitting to, younger caregivers and siblings.

To date, there have been challenges with comparing the roles of children in household spread of SARS-CoV-2 due to small numbers of pediatric cases. Zhu et al. ${ }^{2}$ and Thompson et al..$^{15}$ conducted meta-analyses of studies examining the age of index cases in households, and found that $3 \%-19 \%$ of households had pediatric index cases, depending on the definitions of index cases and pediatric cases ( $<18$ years and $<20$ years, respectively). We identified pediatric index cases aged $<18$ years in approximately $7 \%$ of all households $(6,280 / 89,191$ households), which is similar to studies from Greece $(9 \%<18 \text { years })^{26}$, Switzerland $(8 \%<16 \text { years })^{27}$, Denmark $(5 \%<20 \text { years })^{21}$, Hunan, China $(5 \%$ 
$<15$ years $)^{19}$, and Guangzhou, China $(5 \%<20 \text { years })^{9}$; but higher than studies from South Korea $(3 \%<20 \text { years })^{20}$ and Wuhan, China $(1 \%<20 \text { years })^{12}$, and lower than a study from the USA $(14 \%<18$ years $){ }^{23}$ Presumed household transmission occurred in $27 \%$ of households with a pediatric index case in our study using the 1-14 day definition of secondary transmission (24\% and 16\% using 2-14 and 4-14 day definitions, respectively), which is close to an estimate from Catalonia, Spain $(28 \%) .{ }^{16}$

A small number of studies have compared associations between age of pediatric index cases and household transmission with mixed findings. Our results align with Danish studies from Lyngse et al. ${ }^{21,22}$, which found that among children there were increased odds of transmission with younger age. In the Danish study the OR for children aged 0-5 was 1.11 (95\% CI: 1.01-1.19) compared to the 30-35 year reference group, versus 0.82 (95\% CI: 0.780.85 ) for children aged $10-15 .{ }^{22}$ Soriano-Arandes et al. ${ }^{16}$ also found that the highest OR for transmission was among index cases 0-2 years (2.27, 95\% CI: 0.62-8.35 versus 12-15 year group), but confidence intervals were wide. Grijalva et al. ${ }^{23}$ observed high household secondary attack rates (SAR) for both pediatric and adult index cases in Tennessee and Wisconsin, USA; the SAR for index cases $<12$ years was 53\% (95\% CI: 31\%-74\%) and for cases $12-$ 17 years was $38 \%$ (95\% CI: $23 \%-56 \%$ ). This compared to 55\% (95\% CI: $46 \%-64 \%$ ) for cases $18-49$ years and $62 \%$ (95\% CI: $44 \%-77 \%$ ) for cases $\geq 50$ years. Thompson et al. ${ }^{15}$ conducted a meta-analysis of studies and reported no significant difference in household SAR for index cases 0-9 years versus index cases 10-19 years. Conversely, Park et al. ${ }^{20}$ found that household contacts of index cases 10-19 years had the highest SAR among 10-year age groups of both children and adults at $18.6 \%$ (95\% CI 14.0\%-24.0\%), compared to 5.3\% (95\% CI 1.3\%-13.7\%) for index cases 0-9 years.

Differences in viral shedding, symptom expression, and behavioral factors may explain differences in the odds of household transmission for pediatric age groups across studies. ${ }^{4,521,22}$ Viral load is suspected to be an important factor affecting the odds of SARS-CoV-2 transmission. ${ }^{22,28,29}$ Several studies of age-specific viral shedding of SARS-CoV-2 have reported that viral loads in children are similar or higher than viral loads in adults. ${ }^{22,30-33}$ In particular, one study reported that children $<5$ years of age might carry more viral RNA in their nasopharynx than older children and adults. ${ }^{30}$ Additionally, biases in testing practices, such as the preferential testing of symptomatic cases and contacts, inherently leads to under-detection of pediatric cases and challenges estimating their rates of transmission. ${ }^{4,5,15}$ Studies have found younger children are more likely to be asymptomatic ${ }^{3,16,26}$, which has been 
postulated as a reason for lower infectivity as lower SARs have been reported for asymptomatic index cases compared to symptomatic index cases. ${ }^{2,12,15,24} \mathrm{We}$ found that asymptomatic status and testing delays had strong gradient effects on transmission, similar to our previous study of household transmission. ${ }^{25}$ However, even after adjusting for the lower odds of asymptomatic transmission and testing delays in our study, children 0-3 years and 48 years remained associated with higher household transmission than children 14-17 years. A possible explanation for this finding, as mentioned by Lyngse et al. ${ }^{21}$ and supported by our findings, is that younger children are not able to self-isolate from their caregivers when they are sick, irrespective of the timing of testing. Finally, Li et al. ${ }^{12}$ observed both increased risk of transmission from individuals $<20$ years and faster isolation of pediatric cases in Wuhan, suggesting possible higher infectivity of children compared to adults.

This study has some limitations that should be acknowledged. First, there is the possibility of misclassifying household transmission if secondary case infection was truly acquired outside of the household, or if the true index case of the household was untested. This is particularly relevant for pediatric cases due to their increased probability of having mild or asymptomatic infection, and thus increased probability of infection being missed. We attempted to account for this in sensitivity analyses by modifying the secondary case definition from 1-14 days to 2-14 and 4-14 days, and restricting analysis to symptomatic cases only. Second, this study used multiple evolving data systems for reporting COVID-19 cases in Ontario. As a result, there was some inconsistency regarding how symptoms were reported, which may result in some misclassification of symptomatic cases. We carefully examined the reporting practices over the months covered in the study, and selected a combination of variables (symptoms reported, symptom onset date available, and/or asymptomatic flag) we felt reflected the most likely symptom status of cases. Third, we could not reliably calculate SARs in the study as we did not know the number of non-infected contacts in households for the full cohort. However, after controlling for individual-level household size within the subset of the cohort with this information available, our conclusions were unaltered.

This study also has several strengths. This is a large, population-based study of all individuals with confirmed SARS-CoV-2 infection in Canada's most populated province, thus we had sufficient data to explore transmission within the understudied pediatric group. We were also able to include relevant covariates such as testing delays and household size; our results suggest that early testing of pediatric index cases and reduced household size/crowding may be useful strategies to minimize secondary household transmission. Second, the use of a natural language 
medRxiv preprint doi: https://doi.org/10.1101/2021.03.29.21254565; this version posted March 31, 2021. The copyright holder for this preprint (which was not certified by peer review) is the author/funder, who has granted medRxiv a license to display the preprint in perpetuity.

It is made available under a CC-BY-NC-ND 4.0 International license .

processing algorithm to perform address matching allowed us to reliably identify cases in the same household, rather than relying on contact tracing or other types of epidemiological linkage that would be difficult to perform for high volumes of cases. Third, our application of various sensitivity analyses for symptom status and the definition of secondary transmission increased our certainty of the direction of transmission from index case to secondary case, further supporting our findings.

\section{Conclusion}

As the number of pediatric cases increases worldwide, the role of children in household transmission will continue to grow. We found that younger children are more likely to transmit SARS-CoV-2 infection compared to older children, and the highest odds of transmission were observed for children aged 0-3 years. Differential infectivity of pediatric age groups has implications for infection prevention controls within households and schools/childcare to minimize risk of household secondary transmission. Although children do not appear to transmit infection as frequently as adults, caregivers should be aware of the risk of transmission while caring for sick children in the household setting. As it is challenging and often impossible to socially isolate from sick children, caregivers should apply other infection control measures where feasible, such as use of masks, increased hand washing, and separation from siblings. 


\section{References}

1. Zhang J, Litvinova M, Liang Y, et al. Changes in contact patterns shape the dynamics of the COVID-19 outbreak in China. Science. 2020;368(6498):1481-1486. doi:10.1126/science.abb8001

2. Zhu Y, Bloxham CJ, Hulme KD, et al. A meta-analysis on the role of children in SARS-CoV-2 in household transmission clusters. Clin Infect Dis. 2020. doi:10.1093/cid/ciaa1825

3. Chang T-H, Wu J-L, Chang L-Y. Clinical characteristics and diagnostic challenges of pediatric COVID-19: A systematic review and meta-analysis. J Formos Med Assoc. 2020. doi:10.1016/j.jfma.2020.04.007

4. Hyde Z. Difference in SARS-CoV-2 attack rate between children and adults may reflect bias. Clin Infect Dis. 2021. doi:10.1093/cid/ciab183

5. Goldstein E, Lipsitch M, Cevik M. On the effect of age on the transmission of SARS-CoV-2 in households, schools and the community. medRxiv. 2020. doi:10.1101/2020.07.19.20157362

6. Van Der Hoek W, Backer JA, Bodewes R, et al. De rol van kinderen in de transmissie van SARS-CoV-2. Ned Tijdschr Geneeskd. 2020;164(25):D5140.

7. Ludvigsson JF. Children are unlikely to be the main drivers of the COVID-19 pandemic - A systematic review. Acta Paediatr Int J Paediatr. 2020;109(8):1525-1530. doi:10.1111/apa.15371

8. Arnedo-Pena A, Sabater-Vidal S, Meseguer-Ferrer N, et al. COVID-19 secondary attack rate and risk factors in household contacts in Castellon (Spain): Preliminary report. Rev Enf Emerg. 2020;19(2):64-70.

9. Jing Q-L, Liu M-J, Zhang Z-B, et al. Household secondary attack rate of COVID-19 and associated determinants in Guangzhou, China: A retrospective cohort study. Lancet Infect Dis. 2020;20(10):1141-1150. doi:10.1016/s1473-3099(20)30471-0

10. Dattner I, Goldberg Y, Katriel G, et al. The role of children in the spread of COVID-19: Using household data from Bnei Brak, Israel, to estimate the relative susceptibility and infectivity of children. medRxiv. 2020. doi:10.1101/2020.06.03.20121145

11. Sun K, Wang W, Gao L, et al. Transmission heterogeneities, kinetics, and controllability of SARS-CoV-2. Science. 2021;371(6526):eabe2424. doi:10.1126/science.abe2424

12. Li F, Li Y-Y, Liu M-J, et al. Household transmission of SARS-CoV-2 and risk factors for susceptibility and infectivity in Wuhan: A retrospective observational study. Lancet Infect Dis. 2021. doi:10.1016/s14733099(20)30981-6

13. Xin H, Jiang F, Xue A, et al. Risk factors associated with occurrence of COVID-19 among household persons exposed to patients with confirmed COVID-19 in Qingdao Municipal, China. Transbound Emerg Dis. 2020. doi:10.1111/tbed.13743

14. Wu J, Huang Y, Tu C, et al. Household transmission of SARS-CoV-2, Zhuhai, China, 2020. Clin Infect Dis. 2020. doi:10.1093/cid/ciaa557

15. Thompson HA, Mousa A, Dighe A, et al. Report 38: SARS-CoV-2 Setting-Specific Transmission Rates: A Systematic Review and Meta-Analysis. London, UK; 2020. doi:10.25561/84270

16. Soriano-Arandes A, Gatell A, Serrano P, et al. Household SARS-CoV-2 transmission and children: A network prospective study. Clin Infect Dis. 2021. doi:10.1093/cid/ciab228

17. Bi Q, Wu Y, Mei S, et al. Epidemiology and transmission of COVID-19 in 391 cases and 1286 of their close contacts in Shenzhen, China: A retrospective cohort study. Lancet Infect Dis. 2020;20(8):911-919. doi:10.1016/S1473-3099(20)30287-5

18. Wang Y, Tian H, Zhang L, et al. Reduction of secondary transmission of SARS-CoV-2 in households by face mask use, disinfection and social distancing: A cohort study in Beijing, China. BMJ Glob Heal. 
2020;5(5):e002794. doi:10.1136/bmjgh-2020-002794

19. Hu S, Wang W, Wang Y, et al. Infectivity, susceptibility, and risk factors associated with SARS-CoV-2 transmission under intensive contact tracing in Hunan, China. medRxiv. 2020.

doi:10.1101/2020.07.23.20160317

20. Park YJ, Choe YJ, Park O, et al. Contact tracing during coronavirus disease outbreak, South Korea, 2020. Emerg Infect Dis. 2020;26(10). doi:10.3201/eid2610.201315

21. Lyngse FP, Kirkeby CT, Halasa T, et al. COVID-19 transmission within Danish households: A nationwide study from lockdown to reopening. medRxiv. 2020. doi:10.1101/2020.09.09.20191239

22. Lyngse FP, Mølbak K, Frank KT, Nielsen C, Skov RL, Kirkeby CT. Association between SARS-CoV-2 transmission risk, viral load, and age: A nationwide study in Danish households. medRxiv. 2021. doi:10.1101/2021.02.28.21252608

23. Grijalva CG, Rolfes MA, Zhu Y, et al. Transmission of SARS-COV-2 infections in households Tennessee and Wisconsin, April-September 2020. MMWR Morb Mortal Wkly Rep. 2020;69(44):1631-1634. doi:10.15585/mmwr.mm6944e1

24. Koh WC, Naing L, Chaw L, et al. What do we know about SARS-CoV-2 transmission? A systematic review and meta-analysis of the secondary attack rate and associated risk factors. PLoS One. 2020;15(10):e0240205. doi:10.1371/journal.pone.0240205

25. Paul LA, Daneman N, Brown KA, et al. Characteristics associated with household transmission of SARSCoV-2 in Ontario, Canada: A cohort study. Clin Infect Dis. 2021. doi:10.1093/cid/ciab186

26. Maltezou HC, Vorou R, Papadima K, et al. Transmission dynamics of SARS-CoV-2 within families with children in Greece: A study of 23 clusters. J Med Virol. 2020;93(3):1414-1420. doi:10.1002/jmv.26394

27. Posfay-Barbe KM, Wagner N, Gauthey M, et al. COVID-19 in children and the dynamics of infection in families. Pediatrics. 2020;146(2):e20201576. doi:10.1542/peds.2020-1576

28. Marks M, Millat-Martinez P, Ouchi D, et al. Transmission of COVID-19 in 282 clusters in Catalonia, Spain: A cohort study. Lancet Infect Dis. 2021. doi:10.1016/s1473-3099(20)30985-3

29. Lee LY, Rozmanowski S, Matthew P, et al. An observational study of SARS-CoV-2 infectivity by viral load and demographic factors and the utility lateral flow devices to prevent transmission. Mod Med Microbiol. 2021. http://modmedmicro.nsms.ox.ac.uk/wpcontent/uploads/2021/01/infectivity_manuscript_20210119_merged.pdf.

30. Heald-Sargent T, Muller WJ, Zheng X, Rippe J, Patel AB, Kociolek LK. Age-related differences in nasopharyngeal severe acute respiratory syndrome coronavirus 2 (SARS-CoV-2) levels in patients with mild to moderate coronavirus disease 2019 (COVID-19). JAMA Pediatr. 2020;174(9):902-903. doi:10.1001/jamapediatrics.2020.3651

31. Jones TC, Mühlemann B, Veith T, et al. An analysis of SARS-CoV-2 viral load by patient age. medRxiv. 2020. doi:10.1101/2020.06.08.20125484

32. Yonker LM, Neilan AM, Bartsch Y, et al. Pediatric severe acute respiratory syndrome coronavirus 2 (SARS-CoV-2): Clinical presentation, infectivity, and immune responses. J Pediatr. 2020;227:45-52.e5. doi:10.1016/j.jpeds.2020.08.037

33. L'Huillier AG, Torriani G, Pigny F, Kaiser L, Eckerle I. Culture-competent SARS-CoV-2 in nasopharynx of symptomatic neonates, children, and adolescents. Emerg Infect Dis. 2020;26(10):2494-2497. doi:10.3201/eid2610.202403 
medRxiv preprint doi: https://doi.org/10.1101/2021.03.29.21254565; this version posted March 31, 2021. The copyright holder for this preprint (which was not certified by peer review) is the author/funder, who has granted medRxiv a license to display the preprint in perpetuity. It is made available under a CC-BY-NC-ND 4.0 International license.

Figure 1. Flow diagram of study cohort 
medRxiv preprint doi: https://doi.org/10.1101/2021.03.29.21254565; this version posted March 31, 2021. The copyright holder for this preprint (which was not certified by peer review) is the author/funder, who has granted medRxiv a license to display the preprint in perpetuity.

It is made available under a CC-BY-NC-ND 4.0 International license .

Table 1. Characteristics of pediatric index cases by age group

\begin{tabular}{|c|c|c|c|c|c|}
\hline & $\begin{array}{c}0-3 \text { years } \\
(\mathrm{N}=766)\end{array}$ & $\begin{array}{c}\text { 4-8 years } \\
(\mathrm{N}=\mathbf{1}, 257)\end{array}$ & $\begin{array}{l}\text { 9-13 years } \\
(\mathrm{N}=1,881)\end{array}$ & $\begin{array}{c}14-17 \text { years } \\
(\mathrm{N}=2,376)\end{array}$ & $\begin{array}{c}>17 \text { years } \\
(\mathrm{N}=82,911)\end{array}$ \\
\hline $\begin{array}{l}\text { Age, years (median, } \\
\text { IQR) }\end{array}$ & $2[1,2]$ & $6[5,7]$ & $11[10,12]$ & $16[15,17]$ & $40[28,54]$ \\
\hline \multicolumn{6}{|l|}{ Gender $(\mathrm{N}, \%)$} \\
\hline Female & $374(49.1)$ & $586(46.9)$ & $820(43.9)$ & $1,083(45.7)$ & $39,891(48.3)$ \\
\hline Male & $385(50.5)$ & $663(53.0)$ & $1,045(55.9)$ & $1,283(54.1)$ & $42,572(51.5)$ \\
\hline \multicolumn{6}{|l|}{$\begin{array}{l}\text { Month of disease onset } \\
(\mathrm{N}, \%)\end{array}$} \\
\hline June & $26(3.4)$ & $33(2.6)$ & 35 (1.9) & $63(2.7)$ & $2,945(3.6)$ \\
\hline July & $18(2.3)$ & $30(2.4)$ & 31 (1.6) & $69(2.9)$ & $2,229(2.7)$ \\
\hline August & $13(1.7)$ & $22(1.8)$ & $27(1.4)$ & $81(3.4)$ & $1,744(2.1)$ \\
\hline September & $87(11.4)$ & $155(12.3)$ & $167(8.9)$ & $227(9.6)$ & $8,081(9.7)$ \\
\hline October & $126(16.4)$ & $183(14.6)$ & $299(15.9)$ & $378(15.9)$ & $12,557(15.1)$ \\
\hline November & $186(24.3)$ & $342(27.2)$ & $548(29.1)$ & $638(26.9)$ & $21,934(26.5)$ \\
\hline December & $310(40.5)$ & $492(39.1)$ & $774(41.1)$ & $920(38.7)$ & $33,421(40.3)$ \\
\hline $\begin{array}{l}\text { Testing delay*, days } \\
\text { (median, IQR) }\end{array}$ & $1[0,4]$ & $1[0,4]$ & $2[0,4]$ & $2[0,5]$ & $2[1,4]$ \\
\hline \multicolumn{6}{|l|}{$\begin{array}{l}\text { Testing delay } \\
\text { distribution* }(\mathrm{N}, \%)\end{array}$} \\
\hline Asymptomatic $\dagger$ & $104(15.3)$ & $236(22.5)$ & $324(20.1)$ & $278(13.1)$ & $6,541(9.1)$ \\
\hline$<0$ days $\$$ & $37(5.4)$ & $71(6.8)$ & $72(4.5)$ & $107(5.1)$ & $3,502(4.9)$ \\
\hline 0 days & $97(14.3)$ & $106(10.1)$ & $135(8.4)$ & $166(7.8)$ & $7,069(9.8)$ \\
\hline 1 day & $113(16.6)$ & $149(14.2)$ & $219(13.6)$ & $298(14.1)$ & $11,137(15.5)$ \\
\hline 2 days & $84(12.4)$ & $124(11.8)$ & $223(13.8)$ & $283(13.4)$ & $11,242(15.6)$ \\
\hline 3 days & $69(10.1)$ & $97(9.3)$ & $153(9.5)$ & $242(11.4)$ & $8,794(12.2)$ \\
\hline 4 days & $41(6.0)$ & $54(5.2)$ & $114(7.1)$ & $194(9.2)$ & $6,122(8.5)$ \\
\hline$\geq 5$ days & 135 (19.9) & $211(20.1)$ & $372(23.1)$ & $548(25.9)$ & $17,619(24.5)$ \\
\hline $\begin{array}{l}\text { Average family size } \\
\text { (median, IQR) }\end{array}$ & $3.2[2.9,3.6]$ & $3.2[3.0,3.5]$ & $3.3[3.0,3.6]$ & $3.3[3.1,3.7]$ & $3.3[3.0,3.6]$ \\
\hline $\begin{array}{l}\text { Symptoms reported }(\mathrm{N}, \\
\%)\end{array}$ & $586(76.5)$ & $822(65.4)$ & $1,296(68.9)$ & $1,856(78.1)$ & $65,964(79.6)$ \\
\hline $\begin{array}{l}\text { Associated with a } \\
\text { school/childcare } \\
\text { outbreak }(\mathrm{N}, \%)\end{array}$ & $128(16.7)$ & $229(18.2)$ & 407 (21.6) & $154(6.5)$ & $588(0.7)$ \\
\hline $\begin{array}{l}\text { Before school/childcare } \\
\text { reopening } \S(\mathrm{N}, \%)\end{array}$ & $8(1.0)$ & 99 (7.9) & $108(5.7)$ & $254(10.7)$ & $8,189(9.9)$ \\
\hline $\begin{array}{l}\text { Household size } \\
\text { (median, IQR) }\end{array}$ & $4[3,5]$ & $4[4,5]$ & $4[4,5]$ & $4[4,5]$ & $3[2,4]$ \\
\hline $\begin{array}{l}\text { *778 pediatric index case } \\
\text { reportable disease system } \\
\dagger \text { Index cases that were as } \\
\text { date was used) and were } \\
\text { †ndex cases with a testin } \\
\S \text { Reopening dates: June } 1 \\
\text { outside Toronto, Septem }\end{array}$ & $\begin{array}{l}\text { ere excluded fr } \\
\text { vere missing sy } \\
\text { ptomatic were } \\
\text { orted as asympt } \\
\text { lelay of }<0 \text { days } \\
2020 \text { for index }\end{array}$ & $\begin{array}{l}\text { e testing delay } \\
\text { m onset date, an } \\
\text { fied as cases tha } \\
c \text { in provincial } \\
\text { those who wer } \\
\text { aged } 0-3 \text { years, }\end{array}$ & $\begin{array}{l}\mathrm{s} \text { that had no } \mathrm{C} \\
\text { e not reported } \\
\text { missing symp } \\
\text { able disease sy } \\
\text { d prior to the } \\
\text { mber } 8,2020 \mathrm{f}\end{array}$ & $\begin{array}{l}\text {-19 symptoms } \\
\text { mptomatic. } \\
\text { nset date (thus } \\
\text { f their symptom } \\
\text { ex cases aged }\end{array}$ & $\begin{array}{l}\text { ed in provincial } \\
\text { nen collection } \\
\text { s and residing }\end{array}$ \\
\hline
\end{tabular}


medRxiv preprint doi: https://doi.org/10.1101/2021.03.29.21254565; this version posted March 31, 2021. The copyright holder for this preprint (which was not certified by peer review) is the author/funder, who has granted medRxiv a license to display the preprint in perpetuity. It is made available under a CC-BY-NC-ND 4.0 International license .

Figure 2. Bubble plot of age-to-age transmission 
medRxiv preprint doi: https://doi.org/10.1101/2021.03.29.21254565; this version posted March 31, 2021. The copyright holder for this preprint (which was not certified by peer review) is the author/funder, who has granted medRxiv a license to display the preprint in perpetuity.

It is made available under a CC-BY-NC-ND 4.0 International license .

Table 2. Adjusted odds ratios and 95\% confidence intervals for the associations between index case age group and odds of household transmission

\begin{tabular}{|c|c|c|c|c|c|}
\hline & $\begin{array}{c}\text { Index cases } \\
\text { with } \\
\text { no household } \\
\text { transmission } \\
(\mathrm{N}, \%) \\
\end{array}$ & $\begin{array}{l}\text { Index cases } \\
\text { with } \\
\text { household } \\
\text { transmission } \\
(\mathrm{N}, \%)\end{array}$ & $\begin{array}{l}\text { Crude Model } \\
\text { OR }(95 \% \text { CI })\end{array}$ & $\begin{array}{c}\text { Adjusted } \\
\text { Model 1* } \\
\text { OR (95\% CI) }\end{array}$ & $\begin{array}{c}\text { Adjusted } \\
\text { Model 2† } \\
\text { OR (95\% CI) }\end{array}$ \\
\hline \multicolumn{6}{|l|}{ Age } \\
\hline $0-3$ years & $532(11.7)$ & $234(13.6)$ & $1.20(1.01-1.44)$ & $1.21(1.01-1.45)$ & $1.43(1.17-1.75)$ \\
\hline $4-8$ years & 909 (19.9) & $348(20.3)$ & $1.05(0.90-1.22)$ & $1.06(0.90-1.23)$ & $1.40(1.18-1.67)$ \\
\hline $9-13$ years & $1,382(30.3)$ & $499(29.1)$ & $0.99(0.86-1.13)$ & $0.97(0.85-1.11)$ & $1.13(0.97-1.32)$ \\
\hline 14-17 years & $1,740(38.1)$ & $636(37.0)$ & Ref & Ref & Ref \\
\hline Male gender & $2,433(53.6)$ & $943(55.2)$ & - & $1.07(0.95-1.19)$ & $1.09(0.96-1.23)$ \\
\hline \multicolumn{6}{|c|}{ Month of disease onset } \\
\hline June & $119(2.6)$ & $38(2.2)$ & - & Ref & Ref \\
\hline July & $113(2.5)$ & $35(2.0)$ & - & $0.98(0.58-1.66)$ & $1.05(0.58-1.89)$ \\
\hline August & $112(2.5)$ & $31(1.8)$ & - & $0.89(0.52-1.52)$ & $0.93(0.51-1.69)$ \\
\hline September & $482(10.6)$ & $154(9.0)$ & - & $1.01(0.67-1.51)$ & $0.97(0.62-1.51)$ \\
\hline October & $712(15.6)$ & $274(16.0)$ & - & $1.22(0.82-1.80)$ & $1.20(0.78-1.84)$ \\
\hline November & $1,199(26.3)$ & $515(30.0)$ & - & $1.37(0.93-2.00)$ & $1.38(0.91-2.09)$ \\
\hline December & $1,826(40.0)$ & $670(39.0)$ & & $1.16(0.80-1.70)$ & $1.14(0.76-1.72)$ \\
\hline \multicolumn{6}{|l|}{ Testing delay } \\
\hline Asymptomatic & $853(18.8)$ & $89(5.2)$ & - & - & $0.34(0.25-0.47)$ \\
\hline$<0$ days & $251(5.5)$ & $36(2.1)$ & - & - & $0.50(0.33-0.75)$ \\
\hline 0 days & $1,076(23.8)$ & $206(12.1)$ & - & - & Ref \\
\hline 1 day & $570(12.6)$ & $209(12.3)$ & - & - & $1.24(0.95-1.61)$ \\
\hline 2 days & $488(10.8)$ & $226(13.3)$ & - & - & $1.59(1.22-2.07)$ \\
\hline 3 days & $361(8.0)$ & $200(11.7)$ & - & - & $1.97(1.49-2.59)$ \\
\hline 4 days & $238(5.3)$ & $165(9.7)$ & - & - & $2.38(1.77-3.19)$ \\
\hline$\geq 5$ days & $692(15.3)$ & $574(33.7)$ & - & - & $2.98(2.34-3.80)$ \\
\hline Average family size & $3.3[3.0,3.6]$ & $3.4[3.1,3.7]$ & - & - & $1.63(1.43-1.86)$ \\
\hline
\end{tabular}

*Adjusted for gender and month of disease onset.

$\dagger$ Adjusted for gender, month of disease onset, testing delay, and average family size. 778 index cases were excluded from the model that had no COVID-19 symptoms reported in provincial reportable disease systems, were missing symptom onset date, and were not reported as asymptomatic. 
Excluded cases with missing or incomplete address $(\mathrm{N}=11,439)$

Excluded cases residing in congregate settings $(\mathrm{N}=8,981)$

COVID-19 cases in private households $(\mathrm{N}=148,241)$

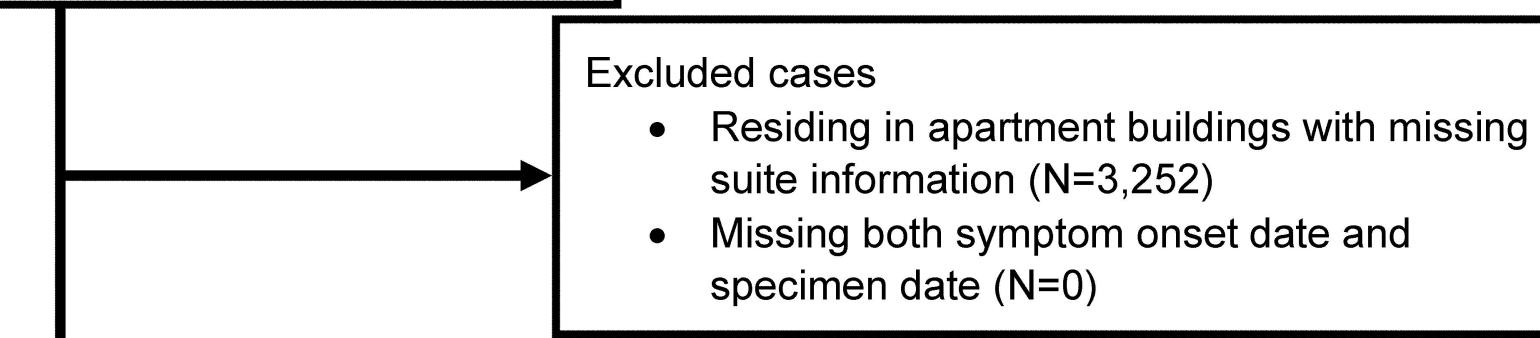

Excluded households

- With index clusters $(\mathrm{N}=12,741$ in 4,335 households)

- With index case missing age ( $\mathrm{N}=16$ in 12 households)

Households with pediatric index cases

( $N=9,861$ in 6,280 households)
Households with adult index cases

( $\mathrm{N}=122,371$ in 82,911 households)
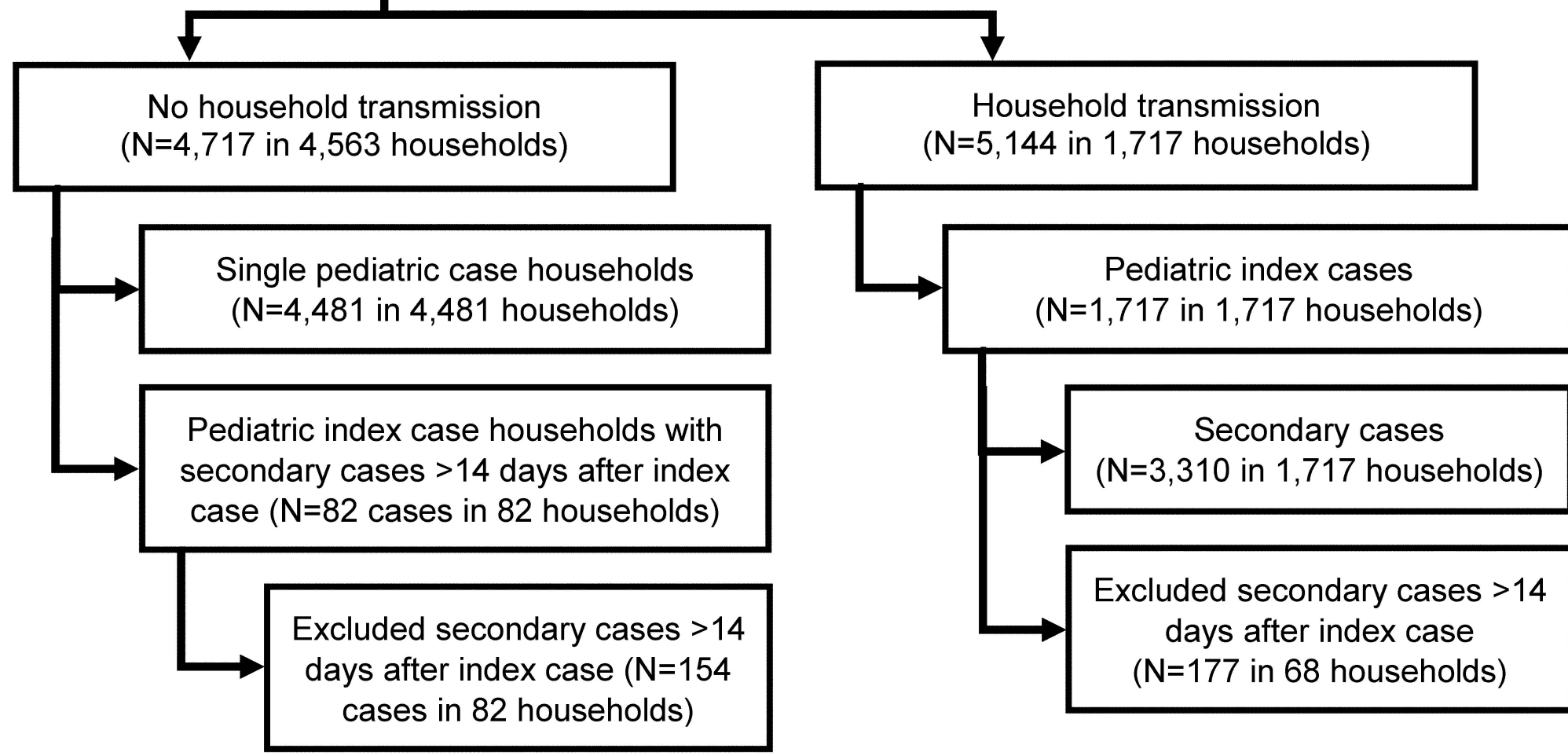


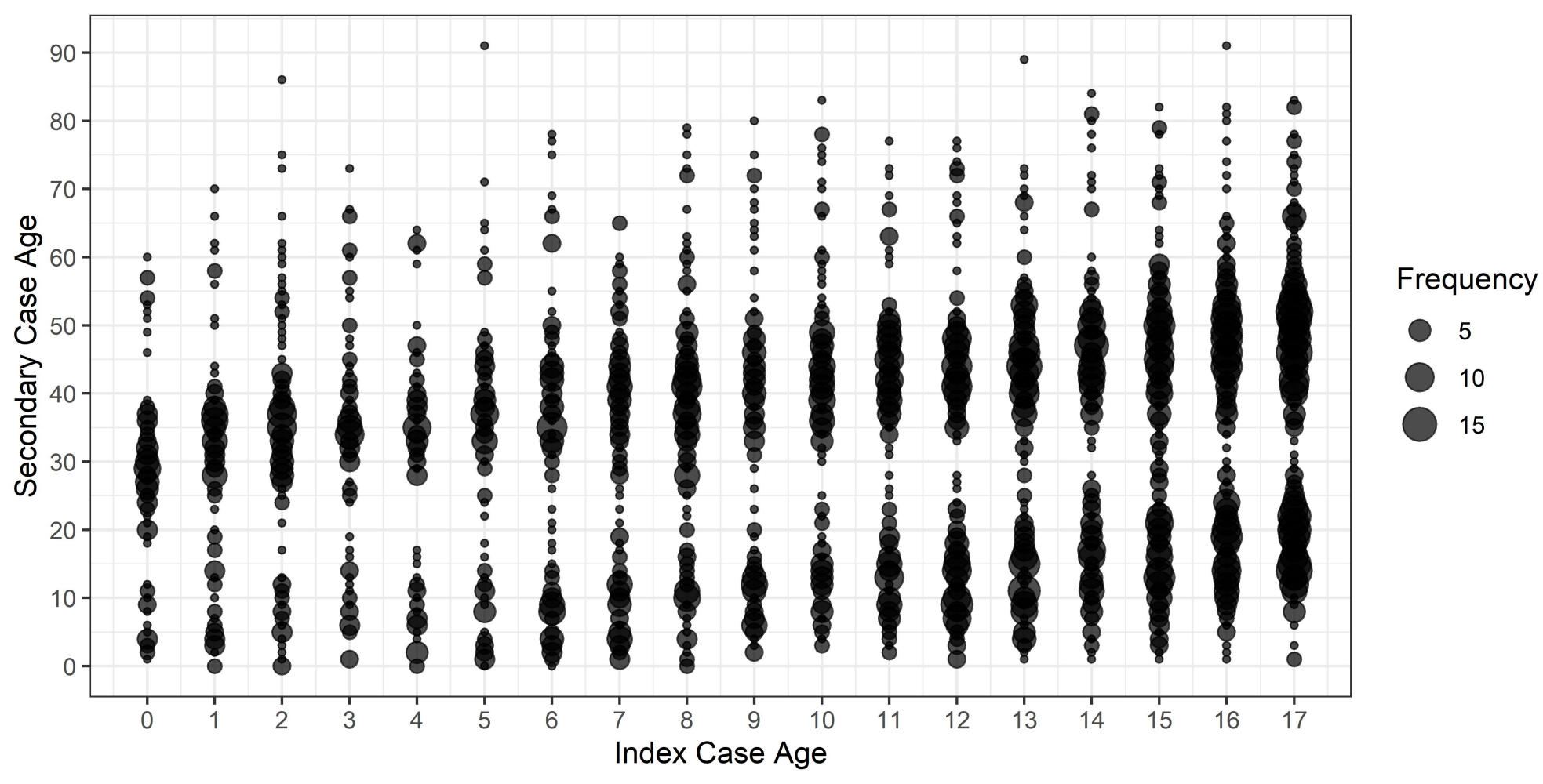

